preservation and collection development.

Postal subsidies. Rep. Bill Ford (D-Michigan) has challenged the library community to come up with better data on postage costs to libraries and to support postal subsidies. This special effort is necessary because, for the first time ever, the Reagan Administration recommended elimination of all postal subsidies, even free mail for the blind. If all subsidy for library rate were removed, a 2-lb. book package would go from 54 cents to 94 cents-a $74 \%$ increase. The library rate subsidy is currently $\$ 42$ million-half of that for the printed and AV materials that libraries, schools, colleges, and other non-profit organizations send among themselves for interlibrary loan, film rentals, textbook distribution, etc., and half for publishers and distributors who are able to mail materials sold to libraries.

With the cooperation of ACRL, the ALA Washington Office surveyed the ACRL 100 institutions to get some data on postal costs. The 53 libraries which sent usable responses spent from $\$ 344$ to $\$ 26,000$ on postage; the average cost was $\$ 5,800$. Can your library afford to lose such support?

White House Conference on Library and Information Services. Legislation is pending for a second White House conference, to be held no later than 1989. The next White House conference is likely to be more focused, probably on information technology advances and the consequent opportunity and challenge for library services. When Frank Newman, in the new report "Higher Education and the American Resurgence" from the Carnegie Foundation for the Advancement of Learning, is saying that these technological advances have moved the research community be- yond the capacity of the research library, that we must evolve from an emphasis on acquisitions to a new system based on access, and that perhaps this new system should not be called "Library," can academic librarians afford not to become involved in the next White House conference?

\section{And, in closing...}

Letters from constituents are important Congressional-influencers. They can demonstrate that the position taken by ACRL and ALA is, in fact, endorsed by and important to its membership. And since, as stated before, letters from constituents have a fighting chance of getting past the staff and to the politicians, they can be the best means of giving politicians the facts they need to make a decision and the rationale they need to defend it.

Write today about the Higher Education Act, next week about postal subsidies, next month about the White House conference. And write about other issues of importance to you. The letters don't have to be long-and they don't even have to be typed. One Congressional staffer said he was more impressed by a hand-written letter than by a typed one-and by letters on plain paper instead of letterhead. You don't think your name should be on the letter? Draft a letter for your Director or Vice President for Academic Affairs to send.

The important thing is to write or make sure someone else in your area does. Because in the era of electronic mail, computer analyses and PAC campaigns, a single letter from a single constituent can still make an all-important difference.

\title{
How to communicate with legislators
}

When to write. It is important to understand the legislative process in order to know when it will be most effective to contact legislators.

A bill may be written by an individual, an agency, a cormmittee, or a subcommittee of one of the houses of Congress. Each bill is assigned to a committee that studies it and decides what action should be taken. Members of the committee should be contacted when the bill is about to come before the committee.

By calling the Bill Status Office in Washington, D.C., at (202) 225-1772 and referring to the bill number, it is possible to find out the date a bill was introduced, the names of its sponsors or cosponsors, the date of committee hearings, and the current status of the bill in the legislative process.

After the bill comes out of committee, it is presented to the full House or Senate. When the bill is about to come before the House or Senate the representative should be contacted if it is a House bill or both Senators if it is a Senate bill.
Legislation requiring federal funding must go through two processes: authorization and funding. If Congress does not appropriate sufficient funds, or if executive agencies cut back on funds, a program can be seriously curtailed. Therefore, after a bill has been passed, it is important to state your views about the need for adequate funding to Congress or to the agency writing the regulations to implement the law.

It is important to lobby for appropriations before April 15 when the Budget Committees of the House and Senate report to their respective bodies the first resolution setting totals for government spending, revenues, deficit and level of public debt for the next fiscal year.

By May 15, the Budget Committees review various pieces of authorization legislation and by September 15 , the second concurrent resolution establishes spending ceilings and a revenue floor. Keep these dates in mind to lobby for appropriations.

Personal visits. Face-to-face discussion is the 
most effective means of communication, and essential to the establishment of a solid working relationship if you do not already know each other. A meeting is more easily arranged early in a session, before pressures build up.

All legislators have one or more district offices. Visits there will often be more convenient for you than in Washington. Members of Congress return periodically (check with the district office), during Congressional recesses, and between sessions.

Constituents are always welcome in Washington. Be sure you have a firm appointment. Use the district office to make local or capitol appointments. Get to know the district office staff (secretaries and administrative assistants) - close working relationships will benefit in many ways.

The following are suggested do's and don'ts to help ensure a successful meeting:

-Do make an appointment by letter or phone and be on time.

-Do outline in your letter or phone call the issues you wish to discuss at the meeting.

- Do prepare a concise, direct presentation which can be complete in a 15-minute meeting.

-Do be well-informed on all aspects of the issues you plan to discuss.

-Do take along others-library director, academic administrator, concerned faculty member. Keep the delegation small enough for an easy exchange of viewpoints.

- Do be a good listener and ask for the legislator's point of view.

-Do have a written statement of the points you wish to make and leave it with the legislator.

-Do leave on good terms even if you have not achieved your ends. You may join forces on another issue at another time.

-Do follow up with a letter of appreciation for the time given to you, and include any additional information suggested by the visit.

-Don't be disappointed if your legislator cannot meet with you. Ask to see a legislative assistant who will be knowledgeable about the legislator's point of view and will convey your message.

-Don't be afraid to admit that you don't have some facts. Say that you will find the answers and report back and do so.

Telephone calls. Once you have made the acquaintance of your representative, telephone calls are appropriate and easy. Make them sparingly to the legislator, whose time is heavily occupied. Regular contact with staff is possible and desirable.

Telephone to ask support before a hearing or floor vote, to ask for help with legislative colleagues, or to convey urgent local concern. Judge how far to pursue by the reaction. Remember that it is more difficult for a legislator to temporize in conversation than by letter.

Writing letters. These are the chief fuel that powers any legislative vehicle. They are read. They elicit responses. They represent votes. Each letter writer is deemed to represent several like-minded if silent constituents.

Letters may be formal or informal, typewritten or handwritten. They should be composed by you, giving the reasons for your position and giving the legislator reasons to support it. If you are asking support for a particular bill, cite it by number and author, and give its title or subject matter. Don't ask for a vote commitment on a particular bill before the committee in charge of the subject has had a chance to hear the evidence and make its report.

Some fundamental do's and don'ts to keep in mind when writing legislators are listed below:

- Do address your senator or representative properly.

- Do share your expert knowledge on libraries and information services with your legislator.

-Do include strong, factual, to the point arguments.

-Do be brief. Limit your letter to one or two pages.

- Do give your full name and address.

-Do write when you approve, not just to complain or oppose.

- Don't use form letters, and avoid including excerpts from other letters on the same subject.

- Don't make threats, promises, or boasts.

- Don't be vague.

-Don't engage in letter-writing overkill.

Suggested forms of salutations for letters to legislators are:

Senator:
The Honorable Daniel Patrick Moynihan
Senate Office Building
Washington, DC 20510
(Dear Senator Moynihan:)

Representative:

The Honorable Geraldine A. Ferraro House Office Building

Washington, DC 20515

(Dear Mrs. Ferraro:)

"Sincerely yours" is in good taste as a complimentary close. Remember to sign your given name and surname. If you use a title in your signature, be sure to enclose it in parentheses.

Where possible use your official letterhead. If this is not in order, and you write as an individual, use plain white bond paper, and give your official title following your signature as a means of identification and to indicate your competency to speak on the subject.

Telegrams and mailgrams. These are fast, easy ways to communicate with legislators and when the need for action is critical - just prior to a committee or floor vote. Use Western Union's nationwide toll-free telephone number: (800) 257-2241.

Editor's Note: Portions of this article are taken from "The Librarian As Lobbyist," by Eleonor E. Pasmik, which appeared in C\&RL News, March 1982; and the ALA Washington Office's flyer, "Ways to Communicate with Legislators." 
New on microfilm . . . from Research Publications

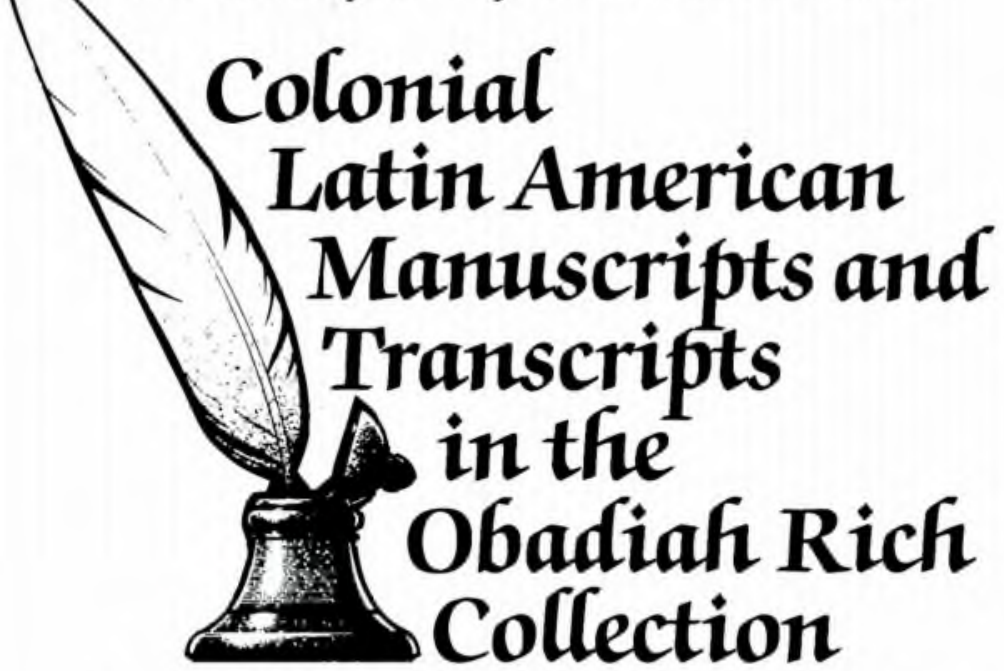

The Obadiafi Rich Collection offers unique and original source material describing the discovery and conquest of the Americas from 1492 to the nineteenth century.

This collection of Spanish and Portuguese documents relates to colonial settlements in North, South, and Central America. Among the 102 volumes are treasurers' reports, colonial records, churchmen's chronicles, historical writings, and accounts of voyages to new colonial settlements - making the Obadiaf Rich Colfection an invafuable source for scholars of Latin American fistory, American studies, archaeology, anthropology, and sociology.

Access to the collection is available through Colonial Latin American Manuscripts and Transcripts in the Obadiaf Rich Coffection: An Inventory and Index by Edwin Blake Brownrigg, which will be supplemented by Research Publications with a reel guide to the micofilm collection.

The collection is priced at $\$ 2,900$ and is scheduled for release in July. For more information, call or write:

Research Publications 12 Lunar Drive/Drawer AB

Woodbridge, CT 06525

(203) 397-2600

TWX: 710-465-6345

FAX: 203-397-3893
Outside North and South America: P.O. Box 45 Reading, RG1 8 HF England TEL: 0734-583247 TELEX: 848336 NADL G FAX: 011-44-734-591325

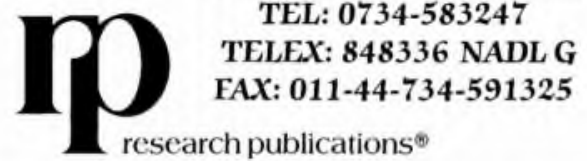

